\title{
Two new species of diving beetles from the Duida-Marahuaca Tepui in Venezuela (Coleoptera: Dytiscidae: Colymbetinae)
}

\author{
Ава новых вида плавунцов с тепуи Ауида-Марауака, Венесуэла \\ (Coleoptera: Dytiscidae: Colymbetinae)
}

\author{
M. Balke ${ }^{1}$, M. Garcia ${ }^{2}$, L. Hendrich ${ }^{1}$ \\ М. Бальке, М. Гарсия, $\Lambda$. Хендрик
}

\footnotetext{
${ }^{1}$ Zoologische Staatssammlung, Münchhausenstrasse 21, D-81247 München, Germany. E-mail: balke.m@snsb.de

${ }^{2}$ Centro de Investigaciones Biológicas (CIB), facultad de Humanidades y Educación, edificio de postgrado, La Universidad del Zulia, apdo. 526, A-4001, Maracaibo, Edo Zulia, Venezuela. E-mail: meruidae2014@gmail.com
}

KEY WORDS: Dytiscidae, Rhantus, new species, Venezuela, tepuis, wing reduction.

КЛЮЧЕВЫЕ СЛОВА: Dytiscidae, Rhantus, новые виды, Венесуэла, тепуи, редукция крыльев.

ABSTRACT. Two diving beetle species Rhantus lattkei sp.n. and Rhantus marahuaca sp.n. are described from the Duida-Marahuaca tepui region in Venezuela. Based on specimens from Merida, Rhantus andinus Balke, 1998 is recorded for the first time in Venezuela. Important species characters (median lobes, parameres and colour patterns) of all species are figured, and notes on their distribution are given. Altogether five species of Rhantus are now known from the country.

РЕЗЮМЕ. С тепуи Дуида-Марауака в Венесуэле описаны два вида плавунцов: Rhantus lattkei sp.n. и Rhantus marahuaca sp.n. Rhantus andinus Balke, 1998 впервые отмечен в Венесуэле по сборам из Мериды. Изображены основные признаки видов (эдеагус, параметры и схемы окраски) всех видов, даны замечания о их распространии. Всего в Венесуэле известно пять видов Rhantus.

\section{Introduction}

Diving beetles of the genus Rhantus Dejean, 1833 are moderately large Dytiscidae, c. $8-14 \mathrm{~mm}$ long. Ninety species are currently assigned to this genus worldwide, after many species were recently transferred to other genera [Balke et al., 2017; Nilsson, Hajek, 2019] based on a comprehensive phylogenetic analysis [Morinière et al., 2016].

Most Rhantus species occur in stagnant water habitats, while few - such as the Pacific island species inhabit pools of low order streams [Balke, Ramsdale, 2006]. Almost all species occuring in the lower latitudes avoid regions under wet tropical climate, i.e. the low- lands [Morinière et al., 2016], while higher altitudes usually feature more narrowly endemic species [Balke, 2001; Balke et al., 2002]. Neotropical species were studied in several recent papers [Trémouilles, 1984; Balke, 1990; 1992; 1993; 1998; Peck, Balke, 1993; Balke et al., 2002]. Nearctic species were revised by Zimmermann \& Smith [1975]. Accepting the current generic delineation, 19 species of Rhantus are known now from the Neotropical region [Balke, 1993, 1998; Balke et al., 2002; Nilsson, Hajek, 2019].

Species so far reported from Venezuela are the widespread Neotropical and Nearctic R. calidus (Fabricius, 1792), as well as $R$. elegans Waterhouse, 1895 (endemic on Roraima Tepui, see also Spangler 1981).

This appears rather depauperate as Venezuela features extended highland regions as well as numerous isolated high plateaus on the Tepuis or Mesas and taking into account that for example the Tres de Junio bog in Costa Rican highlands houses one widespread and two endemic Rhantus species [Balke et al., 2002].

Here we show that Venezuela was simply undercollected, and we describe two new species from the Marawaqa Tepui and provide new records for Rhantus andinus Balke, 1998 from the Andes around Merida. All specimens treated here were discovered in the collection of the MIZA (Maracay, Venezuela) and the MNHN (Paris, France). This underpins the importance of collections as fruitful collection grounds for systematists!

With the species described here, there are altogether four diving beetles known from the plateaus of the Venezuelan tepuis, the characteristic table mountains of the Guyana shield. These beetles are three species of Rhantus (see below) as well as two Tepuidessus Spangler, 1981 [Kodada et al., 2018].

How to cite this article: Balke M., Garcia M., Hendrich L. 2019. Two new species of diving beetles from the Duida-Marahuaca Tepui in Venezuela (Coleoptera: Dytiscidae: Colymbetinae) // Russian Entomol. J. Vol.28. No.3. P.258-262. doi: 10.15298/rusentj.28.3.04 


\section{Materials and Methods}

The beetles were studied with a Leitz MZ6 binocular at 10-50x. Drawings were made with the aid of a camera lucida.

Label data of type material were cited in quotation marks. All type specimens of the herein described species were provided with red labels. The terminology to denote the orientation of the genitalia follows Miller \& Nilsson [2003].

Specimens studied here are deposited in the following institutions: MNHN - Muséum National d'Histoire Naturelle, Paris, France; MIZA — Museo del Instituto de Zoología Agrícola "Francisco Fernández Yépez, Universidad central de Venezuela, Maracay, Venezuela; ZSM - SNSB-Zoologische Staatssammlung München, Germany. The abbreviation MR is used for "microreticulation".

\section{Results}

Rhantus lattkei Balke, Garcia, Hendrich, sp.n. Figs 1, 6-12, 14.

LIFE SCIENCE IDENTIFIER. Registered in Zoobank (www.zoobank.org) as urn:lsid:zoobank.org:act:4215889D-2A8F4D5E-B7AD-89C3D1773C3C.

TYPE LOCALITY. Venezuela: Amazonas state: Duida-Marahuaca National Park: highland below the Cerro Marahuaca (Marahuaca Tepui, Marawaca).

MATERIAL. Holotype, $\sigma^{7}$ (MIZA): "Venezuela: Amazonas state, PN [Parque Nacional] Duida-Marahuaca, Macizo Central [central range], $3^{\circ} 40 \mathrm{~N}, 65^{\circ} 28^{\prime} \mathrm{W}, 1040 \mathrm{~m}, 8$. iii.1985, J. Lattke". Paratype: 1 , same label data (ZSM). The specimens bear our red type labels.

DESCRIPTION. A smaller Rhantus species, total length of holotype $6.5 \mathrm{~mm}$, greatest width $3.3 \mathrm{~mm}$ (paratype 6.2/3.1 $\mathrm{mm}$ ). The beetles are rather parallel-sided in dorsal view (Fig. 1 ); the posterior margin of the pronotum is distinctly concave, the pronotum is thus shorter medially than laterally, and of overall double as head shape.
Colour. Head orange, darker behind the eyes. Pronotum orange, base and anterior margin as well discal area somewhat darkened. Elytron orange with black irrorations. Body appendages, prothorax, prosternal process, epipleuron, coxae, postcoxal process and hind margins of abdominal sternites orange to dark ferrugineous.

Surface sculpture. Head with irregular polygonal meshes and double punctation, densest on frons, no microreticulation (MR) visible; clypeus with double punctation only. Pronotum with double punctation and more-or-less defined polygonal meshes; no MR visible on pronotum. Elytron with distinct, irregular polygonal meshes and fine punctation; devoid of MR within the meshes. Last ventrite with transversally oriented MR and small punctures, without lateral rugae.

Structures. Pronotum with broad and conspicuous lateral bead which distinctly reaches the anterior angle. Prosternal process very short and broadly rounded on ventral side, hardly reaching anterior level of meseocoxae (in other species usually exceeding this level distinctly) (Fig. 12). Lateral wings of metaventrite very narrow (Fig. 14); hind wings vestigial. Last ventrite rounded apically.

Tarsal characters. Protarsal and mesotarsal claws sinuate, shorter than fifth protarsomere (Figs 10-11). Pro- and mesotarsomeres 1-3 only hardly expanded laterally, with four transverse rows of stalked suction discs ventrally. Number of discs per row (tarsomere on which row occurs given in parentheses): 3(1)/4(1)/4(2)/3(3).

Genital structure. Median lobe of aedeagus as in Figs 67 , parameres with only few rather short yellow hairs which are apically acute, not trumpet shaped (Fig. 8).

Female. Gonocoxa as in many other species of the genus, elongate-oval, with numerous short and few stout setae on the tip and along the interior margin (Fig. 9).

ETYMOLOGY.Named for the species' collector, John Lattke. The specific epithet is a substantive in the genitive case.

COMPARATIVE NOTES. A species well-characterized by the following set of features: small size, pronotum double axhead shaped (Fig. 1); prosternal process short, broadly rounded ventrally and almost diamond shaped (Fig. 12); parameres with few short setae only (Fig. 8); lateral wings of metaventrite rather narrow (Fig. 14); hind wings vestigial.
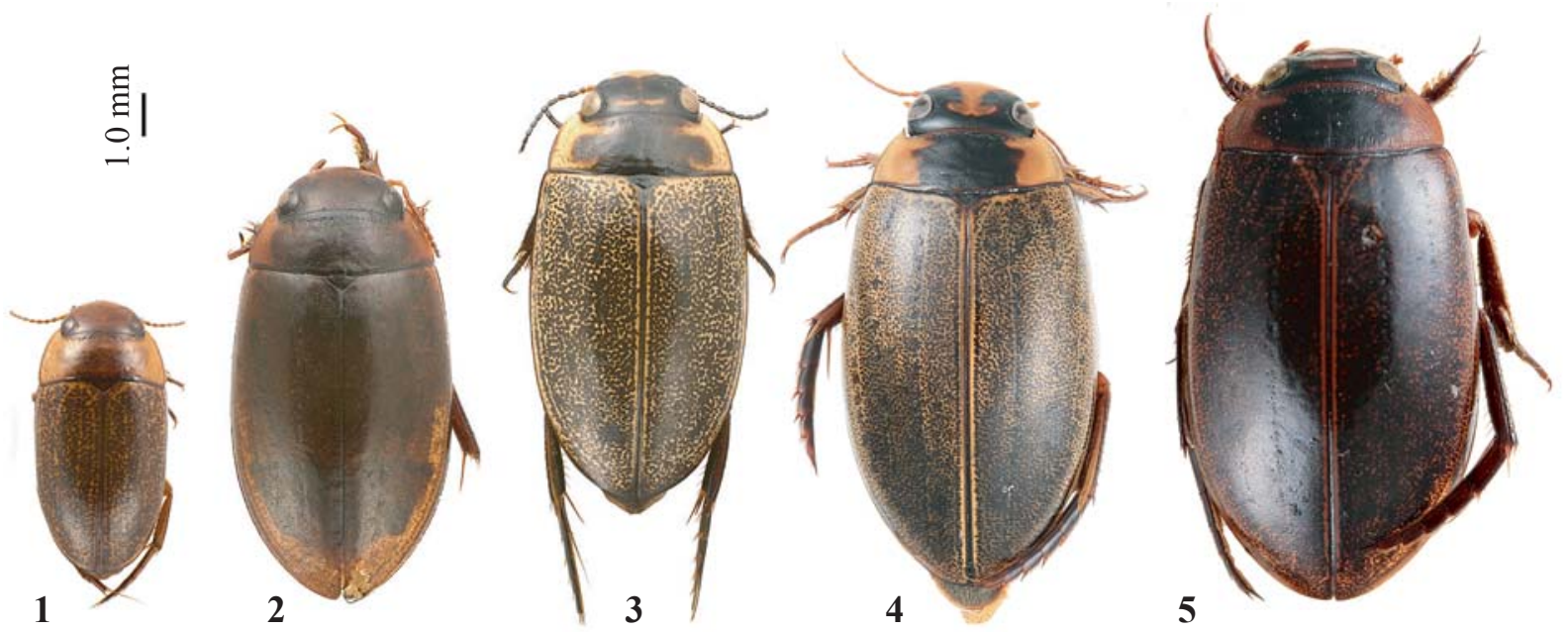

Figs 1-5. Habitus of Rhantus spp.: $1-$ R. lattkei sp.n.; $2-$ R. marahuaca sp.n.; $3-$ R. elegans; $4-$ R. andinus (Colombia, Bogota, La Florida); $5-R$. andinus (Venezuela, Merida, Azulita).

Рис. 1-5. Rhantus spp., внешний вид: $1-$ R. lattkei sp.n.; $2-R$. marahuaca sp.n.; $\quad 3-R$. elegans; $4-R$. andinus (Colombia, Bogota, La Florida); $5-R$. andinus (Venezuela, Merida, Azulita). 
DISTRIBUTION. Rhantus lattkei sp.n. is only known from the type locality.

HABITAT. Most likely small puddles.

Rhantus marahuaca Balke, Garcia et Hendrich, sp.n. Figs 2, 15, 19-21, 23.

LIFE SCIENCE IDENTIFIER. Registered in Zoobank (www. zoobank.org) as urn:1sid:zoobank.org:act:39EF91FE-AA3F-48C588BC-CCC02FFBD0BF.

TYPE LOCALITY. Cerro Marahuaca (Marahuaca Tepui, Marawaca), Duida-Marahuaca National Park, Amazonas state, Venezuela.

MATERIAL. Holotype, ơ (MIZA): Venezuela: Amazonas state: "Marahuaca, 2750 m.a.s.1., 6.-16.x.1983, Exp. Marawaca Fund.[ación] Terramar" (MIZA). Paratype: 1 +, "PN [Parque Nacional] Duida-Marahuaca, Cerro Marahuaca, 2470 m.a.s.1. $\left(3^{\circ} 37 \mathrm{~N} /\right.$ $\left.65^{\circ} 22^{\prime} \mathrm{W}\right), 3 .-6 . i 1.1992$, J. Clavijo \& A. Chacón, Exp. Marawaca Fund.[ación] Terramar" (ZSM). The specimens bear our red type labels.

DESCRIPTION. A medium sized Rhantus. Total length of holotype $9.2 \mathrm{~mm}$, greatest width $4.8 \mathrm{~mm}$ (paratype 9.0/4.6 $\mathrm{mm}$ ). The beetles are elongate oval in dorsal view (Fig. 2); the posterior margin of the pronotum is slightly convex.

Colour (The specimens appear rather darkened, Fig. 2). Head blackish, clypeus dark orange. Pronotum blackish, laterally dark orange. Elytron dark orange with numerous black irrorations and overall dark appearance. Body appendages, prothorax, prosternal process, epipleuron, coxae, and postcoxal process to dark ferrugineous; rest of venter blackish. Fresh specimens are presumably lighter, comparable to a freshly hatched specimen of $R$. elegans figured here (Fig. 3).

Surface sculpture. Head with irregular, deeply impressed polygonal meshes and double punctation; with fine MR visible; clypeus with double punctation only. Pronotum and elytron with fine, in part double punctation and more or less defined, well impressed polygonal meshes; faint microreticulation (MR) visible. MR distinct laterally and apically on elytron. Last ventrite with transversally oriented MR and punctures, with distinct longtitidinal rugae laterally (different in female, see below).

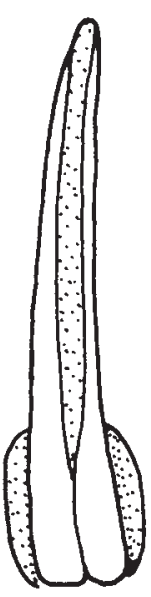

6

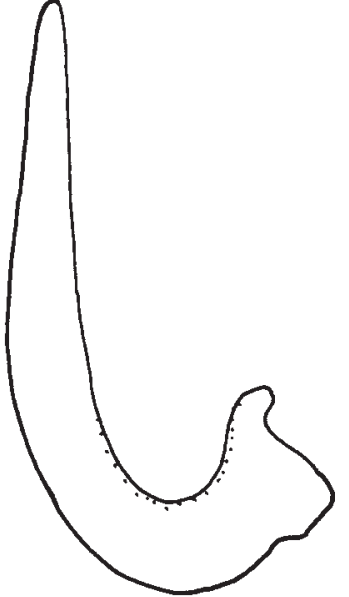

7

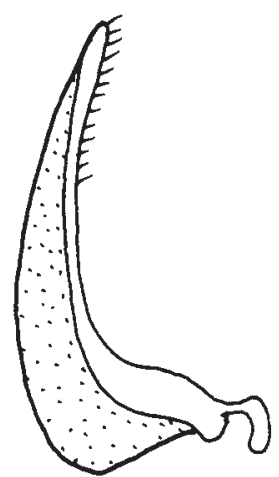

8
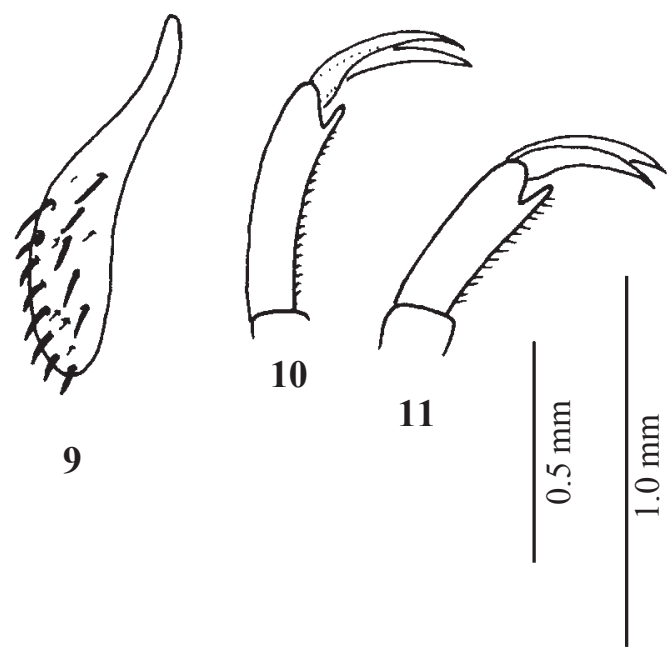
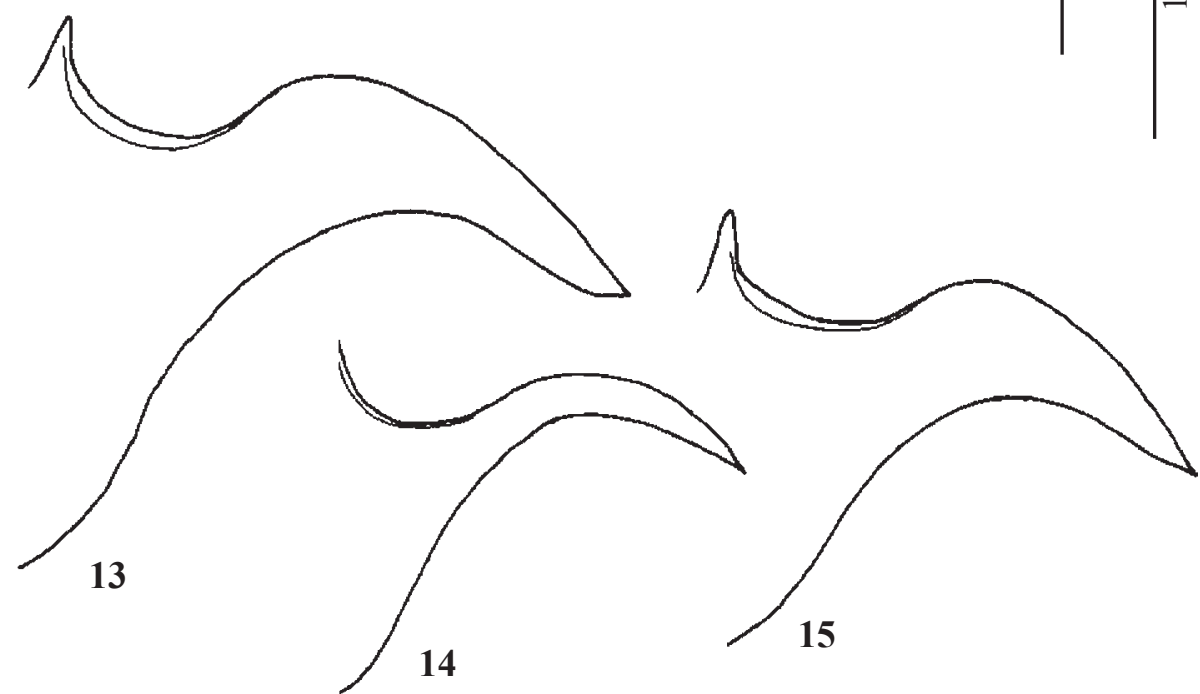

12 14

Figs 6-15. Rhantus spp.: 6-12, $14-$ R. lattkei sp.n.; $13-$ R. elegans; $15-$ R. marahuaca sp.n.; 6-7 - median lobe; 8 - paramere; 9 - gonocoxa; 10 - foretarsus, 11 - middletarsus; 12 - prosternal process and part of metasternum; 13-15 - lateral "wing" of metaventrite; 6, 8-9, 12-15 - ventral; 7 - lateral;10-11 - anterior. Scale bar: $0.5 \mathrm{~mm}$ for 9-11; $1.0 \mathrm{~mm}$ for 6-8, 12-15.

Рис. 6-15. Rhantus spp.: 6-12, $14-R$. lattkei sp.n.; $13-R$. elegans; $15-R$. marahuaca sp.n.; 6-7 - эдеагус; 8 - парамера; 9 - гонокоса; 10 - передняя лапка, 11 - средная лапка; 12 - отросток переднегруди и часть заднегруди; $13-15$ - боковые “крылья" метавентрита; 6, 8-9, 12-15 - снизу; 7 - сбоку;10-11 - спереди. Масштаб: 0,5 мм для 9-11; 1,0 мм для 6-8, $12-15$. 
Structures. Pronotum with broad and conspicuous lateral bead which does not reach the anterior angle. Prosternal process long, narrow, with ventral ridge, reaching almost the hind margin of mesocoxae; fitting into $\mathrm{v}$-shaped counterpart of mesoventrite. Lateral wings of metaventrite narrow (Fig. 15). Flight wings apparently fully developed (the elytra were not removed, but are slightly spread in the female, allowing tentative inspection of flight wings).

Tarsal characters. Protarsal and mesotarsal claws sinuate, shorter than fifth protarsomere (similar to the shape shown in Figs 10-11 for $R$. lattkei sp.n.). Pro- and mesotarsomeres $1-3$ only hardly expanded laterally, with four rows of stalked suction discs ventrally. Number of discs per transverse row (tarsomere on which row occurs given in parentheses): 4(1)/5(1)/5(2)/4(3) (needs confirmation as specimen in poor shape).
Genital structure. Median lobe of aedeagus as in Figs 19-20, surface of basal part rugose; parameres with dense and long setation, setae apically acute, not trumpet shaped (Fig. 21, dotted line = limit of setation). Last ventrite apically slightly truncate; laterally rather rugose (Fig. 23), medially slightly so, with dense punctation but no obvious meshes; base with MR

Female. Elytral meshes slightly more deeply impressed than in male, giving a duller impression. Gonocoxa as in many other species of the genus, elongate-oval, with numerous short and few stout setae on the tip and along the interior margin. Last ventrite apically rounded; laterally with distinct rugae but less so than in male, medially smooth, with dense punctation but no obvious meshes; base with MR.

ETYMOLOGY. Named for the type locality, Cerro Marahuaca.

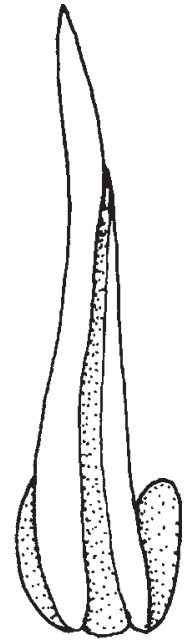

16

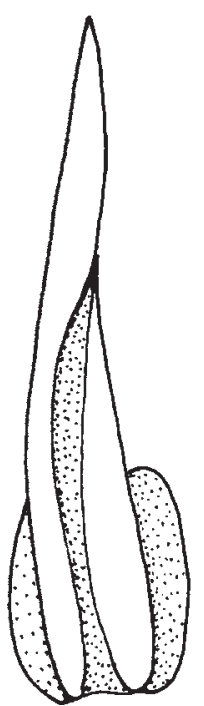

19

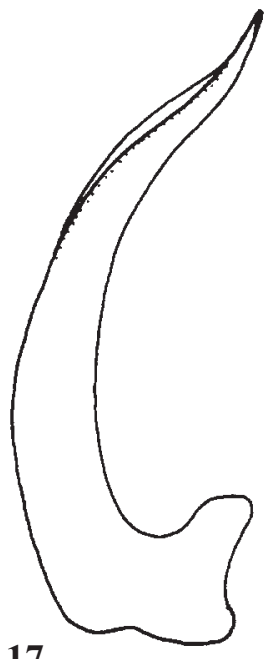

17

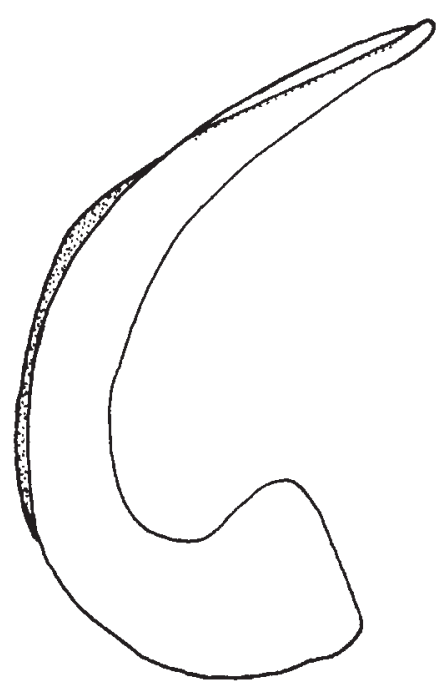

20
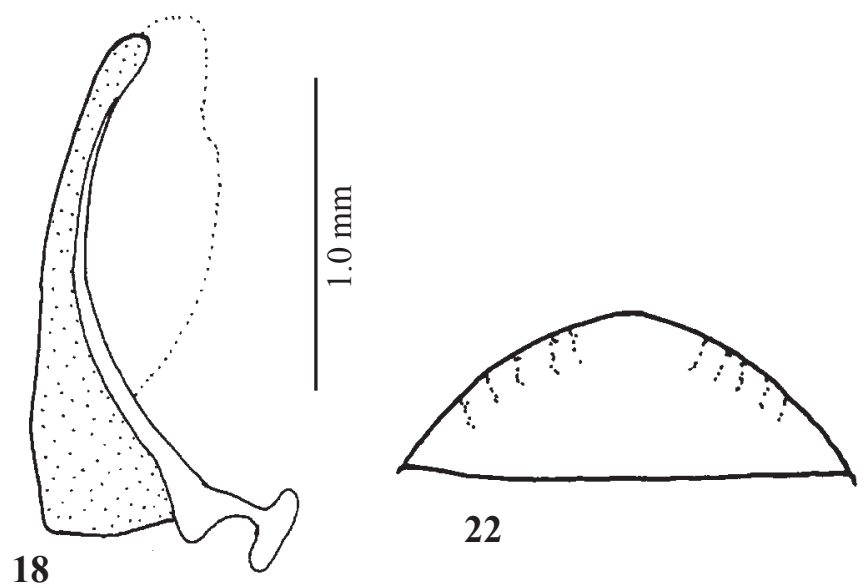

22

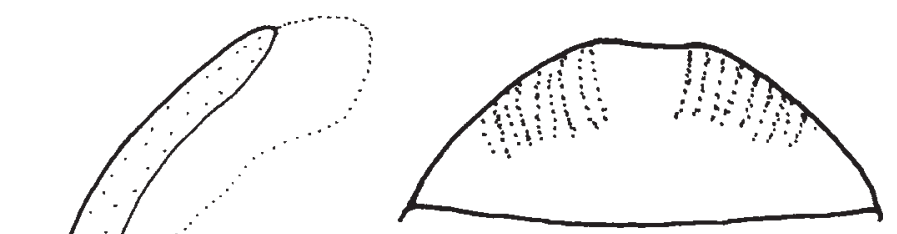

23

Figs 16-23. Rhantus spp.: 16-18, 22 - R. elegans; 19-21, 23 - R. marahuaca sp.n.; 16-17, 19-20 - median lobe; 18, 21 - paramere; 22-23 - last ventrite; 16, 18-19, 21, 22-23 - ventral; 17, 20 - lateral.

Рис. 16-23. Rhantus spp.: 16-18, 22 - R. elegans; 19-21, 23 - R. marahuaca sp.n.; 16-17, 19-20 - эдеагус; 18, 21 - парамера; 22-23 - последний вентрит; 16, 18-19, 21, 22-23 - снизу; 17, 20-сбоку. 
COMPARATIVE NOTES. A smaller Rhantus, male with simply curved claws and predominantly dark pronotum. Similar to $R$. elegans Waterhouse, 1895 from Roraima Tepui ( $550 \mathrm{~km}$ east of Marahuaca). Rhantus marahuaca sp.n. differs from $R$. elegans as follows: Male genitalia (Figs 19-21; $R$. elegans: 16-18), last ventrite: apically rounded and slightly rugose in $R$. elegans (Fig. 22), apically truncate and rather rugose laterally in $R$. marahuaca sp. n. (Fig. 23). Certainly, more specimens need to be examined to evaluate the latter character. The shape of the lateral wings of metaventrite does not differentiate $R$. elegans (Fig. 13) and R. marahuaca sp.n. (Fig. 15).

DISTRIBUTION. R. marahuaca sp.n. is only known from the type locality.

HABITAT. Most likely small puddles.

\section{Rhantus andinus Balke, 1998}

\section{Figs 4-5}

Rhantus andinus Balke, 1998: 73; Nilsson, Hajek 2019: 41. TYPE LOCALITY Colombia, Bogotá [?].

MATERIAL. $10^{7}$ (Fig. 5), Venezuela: Estado Merida, Azulita (Universidad de los Andes agricultural research station), 13.vii.1979,

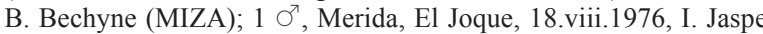
(MIZA); $1 \mathrm{O}^{7}$, Estado Lara, Sanare, 8.ix.1968, J. \& B. Bechyne (MIZA).

NOTES. This is the first record for Venezuela. Balke [1998] observed: "One female may also belong to this species: 'Merida, Venezuela' / 'Rhantus n.sp.' [hand writing M. Régimbart] (MNHN). This specimen differs from the type by: 1) Elytra rather dark due to fusion of most of the black speckles; 2) dorsal surface, especially elytra, matt because the meshes are deeply impressed; 3) base of pronotum distinctly narrower than base of elytra; 4) metasternal wings slightly narrower. This individual may represent a high altitude form of $R$. andinus, or a closely related species." The three males are also of slightly darker coloration than specimens from Bogota (Fig. 4, from La Florida, in ZSM), with slightly more impressed surface sculpture, habitus slightly stouter, posterior fore claw a bit wider and the median lobe slightly straighter along anterior $1 / 3$. Due to the great overall similarity of specimens, we suggest that this case deserves further investigation based on more material from the area in between Bogota and Merida.

Acknowledgements. Michael Balke was supported by the The Linnean Society of London / Systematics Association Small Grants Scheme and a Marie Curie Postdoctoral Fellowship under contract number HPMF-CT-200101365 of the European Commission. We thank Harald Schillhammer (Vienna) for the habitus fotographs of the tepui species, and Max Barclay, curator of the Coleoptera of the Natural History Museum in London, for kind assistance in the examination of Neotropical Rhantus. We thank José Clavijo, John Lattke and Luis Joly for giving us a warm welcome at MIZA during our visit in 2003.

\section{References}

Balke M. 1990. Rhantus souzannae sp.n. from Costa Rica (Coleoptera: Dytiscidae) // Aquatic Insects. Vol.12. P.19-22.

Balke, M. 1992. Taxonomische Untersuchungen an neotropischen Wasserkäfern der Gattung Rhantus Dejean // Reichenbachia. Vol.29. P.27-39.

Balke M. 1993. Neotropische Wasserkäfer der Gattung Rhantus Dejean. IV. Liste und Notizen über die "großen" Arten (Coleoptera: Dytiscidae) // Reichenbachia. Vol.30. P.21-32.

Balke M. 1998. Updating the Pacific, Indomalayan and Neotropical Rhantus-fauna Coleoptera: Dytiscidae) // Koleopterologische Rundschau. Vol.68. P.71-79.

Balke M 2001. Biogeography and classification of New Guinean Colymbetini (Coleoptera: Dytiscidae: Colymbetinae) // Invertebrate taxonomy. Vol.15. P.259-275.

Balke M., Ramsdale A.S. 2006. Rhantus englundi sp.n. from Tubuai Island, French Polynesia (Coleoptera: Dytiscidae) // Koleopterologische Rundschau. Vol.76. P.51-54.

Balke M., Hájek J., Hendrich L. 2017. Generic reclassification of species formerly included in Rhantus Dejean (Coleoptera, Dytiscidae, Colymbetinae) // Zootaxa. Vol.4258. No.1. P.91-100.

Balke M., Roughley R., Sondermann W., Spangler P.J. 2002. Diving beetles of the genus Rhantus in Costa Rica: Taxonomy and biogeography, with notes on South American species (Coleoptera: Dytiscidae) // Studies on Neotropical Fauna and Environment. Vol.37. P.263-271.

Fabricius J.Ch. 1792. Entomologia systematica emendata et aucta. Secundum classes, ordines, genera, species adjectis synonymis, locis, observationibus, descriptionibus. T.I. Pars II. København, Denmark: C.G. Proft. 538 p.

Kodada J., Hendrich L., Balke M. 2018. Tepuidessus grulai sp. nov. from Acopán Tepui in Venezuela (Coleoptera: Dytiscidae: Hydroporinae: Bidessini) // Zootaxa. Vol.4434. No.3. P.561-572.

Miller K. B., Nilsson A.N. 2003. Homology and terminology: Communicating information about rotated structures in water beetles // Latissimus. Vol.17. P.1-4.

Morinière J., Van Dam M.H., Hawlitschek O., Bergsten J., Michat M.C., Hendrich L., Ribera I., Toussaint E.F., Balke M. 2016. Phylogenetic niche conservatism explains an inverse latitudinal diversity gradient in freshwater arthropods // Scientific reports. Vol.6. No.26340. P.1-12.

Nilsson A.N., Hájek J. 2019. A world catalogue of the family Dytiscidae (Coleoptera, Adephaga). 307 pp. Internet version 1.I.2019. Available from: http://www.waterbeetles.eu.

Peck S.B., Balke M. 1993. A synopsis of the Dytiscidae of the Galapagos Islands, Ecuador, with description of Rhantus galapagoensis sp. nov. (Coleoptera: Dytiscidae) // The Canadian Entomologist. Vol.125. P.259-266.

Spangler P.J. 1981. New and interesting water beetles from Mt. Roraima and Ptari-tepui, Venezuela (Coleoptera: Dytiscidae and Hydrophilidae) // Aquatic Insects. Vol.3. P.1-11.

Trémouilles E.R. 1984. El género Rhantus Dejean en la Argentina (Coleoptera, Dytiscidae) // Physis, B. Aires. B. Vol.42. No.102. P.9-24.

Waterhouse C.O. 1895. Insects collected by Messrs. JJ Quelch and F. McConnell on the summit of Mount Roraima // The Annals and Magazine of Natural History, Zoology, Botany and Geology. Ser. 6. Vol.15. P.494-497.

Zimmerman J.R., Smith R.L. 1975. The genus Rhantus (Coleoptera: Dytiscidae) in North America. Part I. General account of the species // Transactions of the American Entomological Society. Vol.101. P.33-123. 